\title{
Ocorrência de Phytophthora parasitica em Lírio da Paz no Brasil
}

\author{
Ivan H. Fischer, Marise C. Martins, Silvia A. Lourenço \& Fabiana M. de Abreu \\ Departamento de Entomologia, Fitopatologia e Zoologia Agrícola, Escola Superior de Agricultura "Luiz de Queiroz", \\ Universidade de São Paulo, Cx. Postal 9, CEP 13418-900, Piracicaba, SP, fax (0xx19) 3434-4839, e-mail: \\ ihfische@esalq.usp.br
}

(Aceito para publicação em 07/05/2004)

Autor para correspondência: Ivan H. Fischer

\begin{abstract}
Occurrence of Phytophthora parasitica in peace lily in Brazil
ABSTRACT

The occurrence of root and crown rot of Spathiphyllum

wallisi caused by Phytophthora parasitica is reported for the first time in the State of São Paulo, Brazil.
\end{abstract}

A planta Spathiphyllum wallisi Regel, conhecida como lírio da paz, é muito usada na decoração de interiores, se adaptando bem em locais sombreados. Em fevereiro de 2003, amostras de lírio da paz, procedentes de estufas de produção, localizadas no município de Cordeirópolis, SP, com necrose do bulbo e conseqüente amarelecimento das folhas baixeiras e murcha das plantas (Figura 1) foram encaminhadas para análise na Clínica Fitopatológica da ESALQ/USP. Procedeuse estudos de diagnose e testes de patogenicidade em mudas sadias, com o objetivo de se identificar o agente causal. Fragmentos de bulbos lesionados, previamente desinfestados em álcool $70 \%$, foram plaqueados em meio de cultura ágarágua, seguido da repicagem para batata-dextrose-ágar (BDA). As placas foram armazenadas em condições ambientais de laboratório sob luminosidade contínua. O isolado obtido apresentou aspecto cotonoso em cultura, micélio cenocítico, esporangióforos e esporângios limoniliformes. O teste de patogenicidade foi realizado através da inoculação de $100 \mathrm{ml}$ de uma suspensão de esporos $\left(10^{4}\right.$ zoósporos $\left./ \mathrm{ml}\right)$ sobre o colo de plantas sadias de lírio da paz, de dois meses de idade. As plantas foram mantidas em casa de vegetação em condições de temperatura ambiente $\left(26^{\circ} \mathrm{C} \pm 3{ }^{\circ} \mathrm{C}\right)$. Para a testemunha utilizou-se apenas água. Com base em análises morfológicas e fisiológicas, o isolado foi identificado como Phytophthora parasitica J. F. Dastur (Ho, H.H. Mycologia 73:705-714, 1981), apresentando esporângios limoniformes, papilados (Figura 2) e não caducos. Houve crescimento micelial em meio de cultura BDA, a $37{ }^{\circ} \mathrm{C}$, e uma maior formação de esporângios quando as culturas foram mantidas em água. A reprodução dos sintomas de $P$. parasitica em $S$. wallisi foi confirmada após seis dias da inoculação. Observou-se necrose da haste, seguida de murcha e morte das plantas. O patógeno foi reisolado dos tecidos infetados, comprovando sua patogenicidade. Este é o primeiro relato da ocorrência de $P$. parasitica afetando lírio da paz no Brasil.

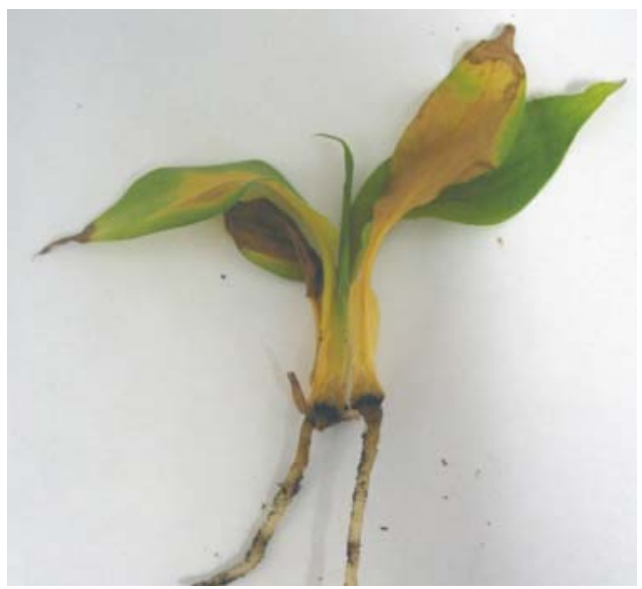

FIG. 1 - Sintomas causados por Phytophthora parasitica em planta de lírio da paz Spathiphyllum wallisi.

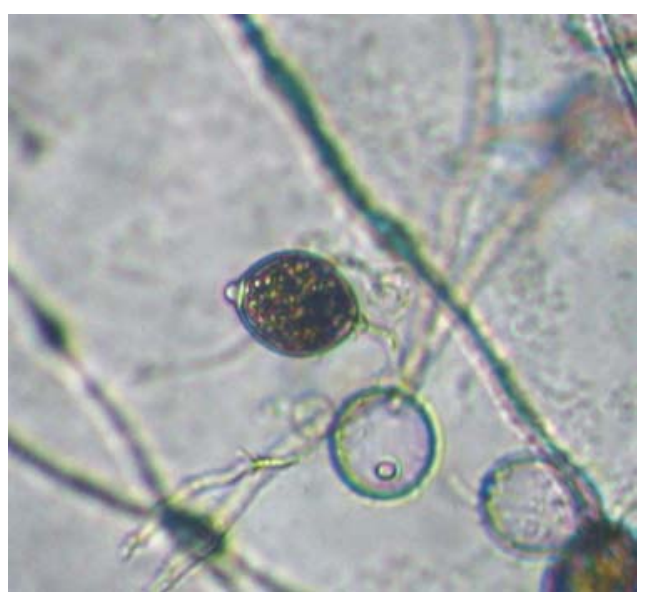

FIG. 2 - Esporângios de Phytophthora parasitica obtido de lírio da paz (Spathiphyllum wallisi). 